Original Research Paper

\title{
Peningkatan Kompetensi Guru Biologi Melalui Pendampingan Kegiatan Pembelajaran Berbasis Lesson Study Di SMAN 1 Lembar
}

\author{
Jamaluddin $^{1,2 *}$, A. Wahab Jufri, ${ }^{1,2}$, Agus Ramdani ${ }^{1,2}$, Afriana Azizah ${ }^{1}$ \\ ${ }^{1}$ Program Studi Pendidikan Biologi Fakultas Keguruan dan Ilmu Pendidikan, Universitas Mataram \\ ${ }^{2}$ Program Studi Magister Pendidikan IPA Pascasarjana, Universitas Mataram.
}

*Corresponding Author:

Jamaluddin, Program Studi Pendidikan Biologi Fakultas Keguruan dan Ilmu Pendidikan, Universitas Mataram, Indonesia; Email:

jamaluddin.fkip@unram.ac.id

\begin{abstract}
Abstrak: Tujuan kegiatan pengabdian pada masyarakat ini adalah untuk, 1) meningkatkan kualitas perencanaan pembelajaran biologi (penyusunan perangkat pembelajaran) dengan menerapkan pola lesson study di SMA Negeri 1 Lembar, 2) meningkatkan kualitas proses pembelajaran biologi dengan menerapkan pola lesson study di SMA Negeri 1 Lembar, dan 3) meningkatkan kualitas cara mengevaluasi pembelajaran dengan menerapkan pola lesson study di SMA Negeri 1 Lembar. Manfaat yang dapat diperoleh melalui kegiatan pengabdian pada masyarakat ini antara lain, 1) secara praksis dapat meningkatkan kualitas pembelajaran biologi melalui penerapan model-model pembelajaran inovatif denganpola lesson studi, 2) dapat mengembangkan kompetensi pedagogik guru khususnya dalam merencanakan, melaksanakan, dan mengevaluasi pembelajaran dengan pola lesson studi, 3) hasil yang akan diperoleh dapat digunakan sebagai acuan dalam merencanakan, melaksanakan, dan mengevalusai pembelajaran biologi dengan pola lesson studi. Kegiatan pengabdian pada masyarakat ini akan dilaksanakan melalui tiga tahap, yaitu 1) sosialisasi dan focus group discussion tentang materi lesson study, 2) pendampingan pembuatan perangkat pembelajaran dengan pola lesson studi, 3) pendampingan pada saat melaksanakan dan mengevaluasi pembelajaran dengan pola lesson studi. Metode yang digunakan dalam kegiatan ini antara lain adalah, 1) diskusi informasi terkait dengan konsep, prosedur, best practice tentang lesson study, 2) praktek langsung penyusunan perangkat pembelajaran, pelaksanaan proses pembelajaran, dan evaluasi pembelajaran dengan pola lesson studi. Hasil yang diharapkan dapat dicapai melalui kegiatan ini sesuai dengan tujuan yang telah direncanakan, yaitu 1) meningkatnya pemahaman pendidik biologi tentang konsep dan prosedur pembelajaran biologi dengan pola lesson studi, 2) meningkatnya keterampilan pedidik biologi dalam merancang dan melaksanakan pembelajan biologi dengan pola lesson studi, dan 3) meningkatnya keterampilan pendidik biologi dalam mengevaluasi pembelajaran yang telah dilakukan denga pola lesson studi.
\end{abstract}

Kata Kunci: Kompetensi Pendidik Biologi, Kegiatan Pembelajaran, Lesson Study.

\section{Pendahuluan}

Dalam rangka meningkatkan mutu
pendidikan di Indonesia pemerintah telah
mengesahkan Undang-Undang RI Nomor 14 Tahun
2005 tentang Pendidik dan Dosen. Undang-undang
tersebut mengamanatkan
penyelenggaraan pendidikan dan penyesuaian
terhadap pendidik-pendidik agar menjadi
profesional. Sehubungan dengan hal itu, upaya

perbaikan tersebut di satu sisi telah menampakkan hasil yang menggembirakan namun di sisi lain masih banyak yang perlu dibenahi terutama terkait dengan kualitas pembelajaran yang disajikan pendidik di hadapan siswa di kelas.

Peningkatan kualitas pembelajaran di kelas yang dilakukan oleh pendidik merupakan hal penting yang perlu mendapat perhatian sungguhsungguh dalam proses pendidikan. Namun, pada kenyataannya layanan pendidikan berkualitas 
belum sepenuhnya didapatkan oleh peserta didik. Salah satu faktor penting penyebab rendahnya mutu pendidikan dan pembelajaran adalah pendidik. Pendidik sebagai tenaga pengajar memegang peranan penting dalam berhasil tidaknya suatu pendidikan di sekolah. Agar proses pembelajaran di sekolah dapat berlangsung sebagaimana yang diharapkan maka keprofesionalan pendidik hendaknya tetap dijaga dengan berbagai cara. Berbagai upaya telah dan sedang dilakukan pemerintah untuk meningkatkan keprofesionalan pendidik. Syamsuri dan Ibrohim (2011) menyatakan bahwa salah satu program alternatif yang dapat terus dilakukan untuk meningkatkan keprofesionalan pendidik adalah melalui kegiatan lesson study.

Lesson study merupakan model pembinaan profesi pendidik melalui pengkajian pembelajaran secara kolaboratif dan berkelanjutan berdasarkan prinsip-prinsip kolegialitas dan mutual learning, serta membangun learning community. Tujuan utama lesson study menurut Rusman (2010) adalah: (1) memperoleh pemahaman yang lebih baik tentang bagaimana siswa belajar dan pendidik mengajar, (2) memperoleh hasil-hasil tertentu yang bermanfaat bagi para pendidik lainnya dalam melaksanakan pembelajaran, (3) meningkatkan pembelajaran secara sistematis melalui inquiry kolaboratif, (4) membangun sebuah pengetahuan pedagogis, di mana seorang pendidik dapat menimba pengetahuan dari pendidik lainnya.

Lesson study juga merupakan salah satu alternatif guna mengatasi masalah praktik pembelajaran yang selama ini dipandang kurang efektif. Sejalan dengan hal tersebut lesson study dapat memberikan "unsur kunci" yang hilang dalam reformasi pendidikan, yaitu cara efektif untuk meningkatkan kualitas pembelajaran melalui pengembangan profesionalisme pendidik yang dilaksanakan secara kolaboratif berdasarkan praktik pembelajaran (Susilo, dkk., 2010). Melalui kegiatan lesson study secara kolaboratif pendidik dapat mengembangkan perangkat pembelajaran yang diperlukan, mengevaluasi proses pembelajaran yang dilakukan, dan pada gilirannya dapat meningkatkan proses serta hasil belajar sebagaimana yang diharapkan (Syamsuri dan Ibrohim, 2011).

Praktik pembelajaran yang dilakukan oleh pendidik selama ini dipandang kurang efektif, yaitu cenderung dilakukan secara konvensional melalui teknik komunikasi verbal. Praktik pembelajaran semacam ini lebih menekankan pada pendidik sebagai satu-satunya sumber informasi (teacher centered) daripada bagaimana siswa belajar (student centered). Cara seperti ini ternyata tidak banyak memberikan kontribusi terhadap peningkatan mutu proses dan hasil pembelajaran siswa. Oleh karena itu perlu ada upaya secara sistemik dan berkelanjutan untuk meningkatkan kualitas pembelajaran yaitu melalui lesson study. Untuk memecahkan permasalahan tersebut di atas maka dilaksanakan kegiatan pengabdian pada masyarakat ini dalam bentuk pelatihan dan pendampingan dengan langkah-langkah: 1) memberikan pemahaman tentang konsep, prosedur dan proses merencanakan pembelajaran, melaksanakan pembelajaran, dan mengevaluasi pembelajaran dengan menerapkan pola lesson study, 2) melakukan pendampingan dalam merencanakan pembelajaran/ menyusun perangkat pembelajaran dengan pola lesson study, 3) melakukan pendampingan pada saat pendidik melaksanakan dan mengevaluasi pembelajaran dengan menerapkan pola lesson study.

Tujuan dan manfaat dari kegiatan pengabdian pada masyarakat ini adalah untuk: 1) Meningkatkan kualitas perencanaan pembelajaran IPA (penyusunan perangkat pembelajaran) dengan menerapkan pola lesson study di SMA Negeri 1 Lembar. 2) Meningkatkan kualitas proses pembelajaran IPA dengan menerapkan pola lesson study di SMA Negeri 1 Lembar. 2) Meningkatkan kualitas cara mengevaluasi pembelajaran dengan menerapkan pola lesson study di SMA Negeri 1 Lembar.

Kegiatan pengabdian pada masyarakat ini dapat memberikan manfaat terutama kepada pendidik SMA Negeri 1 Lembar dan peserta didik dalam hal: 1) Secara praktis dapat meningkatkan kualitas pembelajaran IPA melalui penerapan model-model pembelajaran inovatif. 2) Dapat mengembangkan kompetensi pedagogik pendidik khususnya dalam merencanakan, melaksanakan, dan mengevaluasi pembelajaran yang bermutu. 3) Hasil yang akan diperoleh dapat digunakan sebagai acuan dalam merencanakan, melaksanakan, dan mengevalusai pembelajaran yang pada gilirannya dapat meningkatkan kualitas hasil belajar peserta didik.

Kegiatan pengabdian ini terkait dengan upaya peningkatan kompetensi pedagogik para pendidik 
di SMAN 1 Lembar. Luaran dari kegiatan pengabdian pada masyarakat ini berupa peningkatan kompetensi pendidik dalam menyusun perangkat pembelajaran berbasis lesson study. Perangkat pembelajaran dimaksud dikembangkan berdasarkan pendekatan saintifik dengan pola lesson studi dalam penerapannya di kelas. Kegiatan pengabdian ini telah terlaksana sesuai dengan rencana. Realisasi pemecahan masalah dapat terealisasi dengan baik, hal ini terbukti dengan antuasiasme peserta dalam mengikuti kegiatan, jumlah peserta yang hadir memenuhi persyaratan keterlaksanaan kegiatan yaitu dihadiri oleh 23 orang pendidik mata pelajaran Biologi yang tergabung Musyawarah Pendidik Mata Pelajaran (MGMP) Biologi Lombok Barat. Suasana diskusi antara tim pengabdian dengan peserta berlangsung dengan interaktif

\section{Metode Pelaksanaan}

Metode yang digunakan dalam pelaksanaan kegiatan pengabdian pada masyarakat ini adalah metode diskusi informasi, latihan dan penugasan. Kemudian dilanjutkan dengan kegiatan pendampingan. Dalam mengembangkan perangkat pembelajaran berbasis lesson study yang telah direkomendasikan oleh Kemendikbud dalam implementasi Kurikulum 2013 menggunakan pendekatan saintifik. Model-model pembelajaran dimaksud adalah Discovery learning, Problem Base learning, dan Inquiry learning. Penerapan perangkat pembelaajran biologi menggunakan pola lesson studi.

Agar kegiatan pengabdian dapat mencapai tujuannya dengab optimal maka metode yang digunakan dalam kegiatan PPM adalah: 1) Metode diskusi informasi, digunakan untuk menjelaskan kepada peserta pengabdian tentang pengertian, konsep dan prosedur pembelajaran biologi berbasis lesson studi. 2) Metode Tanya jawab, digunakan untuk memberikan peluang kepada peserta PPM untuk bertanya tentang konsep atau prosedur pembeljaran biologi berbasis lesson study. Pertranyaan yang diajukan kemudian dijawab oleh anggota tim pengabdian melalui moderator yang mengatur kegiatan PPM. 3) Metode diskusi, memberikan kesempatan kepada peserta PPM untuk memperdalam pemahamannya tentang pembelajaran biologi dengan pola lesson study.
Penugasan, digunakan untuk menugaskan kepada peserta untuk berlatih melaksanakan pembelajaran biologi dengan pola lesson studi yang padukan dengan pendekatan saintifik.pendekatan saintifik.

\section{Hasil dan Pembahasan}

Kegiatan pengabdian pada masyarakat ini, telah terlaksana sesuai dengan rencana. Peserta kegiatan pengabdian ini diikuti oleh pendidikpendidik MTs Al Aziziah Gunungsari yang merupakan pendidik tetap dari semua mata pelajaran. Selama kegiatan pengabdian peserta mengikutinya dengan semangat, karena materi kegiatan pengabdian yang disampaikan oleh tim sangat relevan dengan kebutuhan tugas mereka sebagai pendidik. Disisi lain selama ini mereka belum pernah melaksanakan kegiatan pembelajaran dengan pola Lesson Study.

Perencanaan dan pelaksanaan pembelajaran biologi yang dilakukan oleh para pendidik biologi SMA selama ini adalah kegiatan pembelajran biasa tanpa menggunakan pola lesson study. Mereka belum pernah menguti pelatihan tentang implentasi Kuriukulum 2013 berbasis dengan pendekan saintifik dengan pola lesson study. Untuk itu dengan telah terlaksananya kegiatan pengabdian ini merupakan hal yang sangat bermanfaat bagi pendidik biologi di SMA.

Keterlaksanaan kegiatan pengabdian pada masyarakat ini telah memberikan kontribusi yang amat berharga bagi pendidik biologi SMA masih membutuh bimbingan dan pelatihan dalam merencanakan, melaksanakan, dan mengevaluasi proses pembelajaran dengan pola lesson studi. Dari hasil kegiatan pengabdian ini para pendidik biologi SMA tersebut telah memperoleh beberapa manfaat diantaranya: 1) Meningkatkan pemahaman mereka tentang konsep dan prosedur penyusunan perencanaan pembelajaran dengan pola lesson studi. 2) Memperluas wawasan mereka tentang analisis kurikulum khususnya tentang analisis Kompetensi Inti dan Kompetensi dasar menjadi sejumlah Indikator pencapaian kompetensi. 3) Menambah pemahaman mereka tentang implementasi pendekatan saintifik dalam perencanaan dan pelaksanaan pembelajaran bologi di SMA dengan pola lesson studi, hal ini sesuai dengan anjuran Kemendikbud dalam penerapan 
Kurikulum 2013. Pemahaman tersebut amat penting dalam upaya mempersiapkan generasi emas Indonesia yang diharapkan tercapai pada tahun 2045. 4) Para pendidik biologi SMA telah memiliki pemahaman yang lebih baik tentang konsep dan prosedur pembelajaran dalam implementasi kurikulum 2013 dengan pola lesson study. Dalam hal ini para pendidik telah memperoleh materi tentang Pengertian dan prosedur lesson studi, pengembangan perangkat pembelajaranm dengan pola lesson Studi, dan evaluasi pembelajaran degan pola lesson studi.

Materi kegiatan PPM yang disampaikan adalah tentang perencanaan dan pelaksanaan pembelajaran biologi dengan pola lesson studi Materi tersebut merupakan materi yang sangat mendukung kompetensi paedagogik pendidik biologi di SMA. Dengan demikian materi tersebut merupakan hal yang menjadi kebutuhan para pendidik yang terlibat dalam kegiatan PPM ini. Materi kegiatan ini merupakan salah satu materi pokok dari yang harus dikuasai para pendidik untuk menjadi pendidik yang profesional. Dukungan Kepala Sekolah dan para pendidik yang begitu antusias sanagt mendukung terlaksananya kegiatan PPM ini. Adanya faktor-faktor pendukung tersebut maka kegiatan pengabdian ini dapat berjalan dan mancapai hasil sesuai dengan tujuan kegiatan pengebdian pada masyarakat ini.

Hambatan-hambatan yang ditemukan dalam pelaksanaan kegiatan pengabdian pada masyarakat ini diantaranya adalah minimnya sumber belajar yang berkaitan dengan upaya pengembangan peragkat pembelajaran berbasis lesson studi yang dipadukan dengan ketentuan Permendikbud nomor 22 tahun 2016 dan pendekatan saintifik. Hambatan tersebut diantanya adalah buku-buku tentang model model pembelajaran yang dimiliki oleh para pendidik biologi sesuai dengan yang dianjurkan dalam implementasi Kurikulum 2013. Hal ini telah menyebabkan kesulitan bagi pendidik dalam menyusun perangkat pembelajaran dengan pola lesson studi. Untuk mengatasi hambatan ini tim pengabdian membantu peserta untuk memperoleh bahan sebagai acuan untuk mengembangan perangkat pembelajaran.

Bahan-bahan atau metri pelahan yang telah diberikan kepada para peserta pengabdian dalam bentuk Fotocopian yang terdiri dari materi konsep dan prosedur perencaan pembelajaran dengan pola lesson studi, prosedur kajian dan analisis KI dan KD dalam implementasi kurikulum 2013, konsep dan prinsip pendekatan saintifik, dan materi modelmodel pembelajaran dalam implementasi kurikulum 2013. Semua materi tersebut merupakan materi yang dapat digunakan oleh para pendidik biologi di SMA dalam merancang, melaksanakan dan mengevaluasi pembelajaran biologi dengan pola lesson studi.

\section{Kesimpulan}

Kegiatan pengabdian pada masyarakat tentang Peningkatan Kompetensi Guru Biologi Melalui Pendampingan Kegiatan Pembelajaran Berbasis Lesson Study di SMAN 1 Lembar. Kegiatan tersebut telah mencapai tujuan PPM ini yaitu 1) Meningkatkan kualitas perencanaan pembelajaran dengan menerapkan pola lesson study; 2) meningkatnya kualitas proses pembelajaran biologi dengan menerapkan pola lesson study.3) meningkatnya kemampuan pedidik dalam mengevaluasi pembelajaran dengan menerapkan pola lesson study di SMA Negeri 1 Lembar. Kegiatan PPM ini dinilai sangat bermanfaat bagi pendidik-pendidik yang menjadi peserta dalam kegiatan pengebadian masyarakat ini. Melalui kegiatan dimaksud para peserta telah memiliki wawasan tentang konsep, prosedur dan system evaluasi kegiatan pembelajran biologi dengan pola lesson studi di SMA.

\section{Saran}

Peningkatan kompetensi pendidik biologi SMA khususnya dalam merancang, melaksanakan dan mengevaluasi pembelajaran biologi dengan pola lesson studi dalam implemetasi Kurikulum 2013. Kepada para pendidik yang terlibat sebagai peserta kegiatan pengabdian disarankan: 1) Pendidik biologi di SMA hendaknya terus meningkatkan komitmen untuk berupaya mengembangkan kompetensi paedagogiknya dalam merancang, melaksanakan dan mengevaluasi kegiatan pembelajaran biologi dengan pola lesson studi. 2) Pendidik biologi SMAharus terus belajar menerapkan model-model pembelajaran yang disarankan dalam penerapan pendekatan saintifik. 
Diantaranya model pembelajaran dimaksud adalah discovery learning, inquiri learning, problem base learning, project base learning dan model-model pembelajaran lainnya yang relevan untuk penerapan kurikulum 2013. Penerapan model-model pembelajaran tersebut dapat dipadukan dengan pola lesson studi. 3) Pendidik Biologi SMA yang telah mampu melaksanakan pembelajran biologi dengan pola lesson studi agar bersedia berbagi untuk teman sejawat yang lainnya. Dengan cara ini dapat diharapkan para pendidik biologi SMA semuanya dapat merancang, melaksanakan, dan mengevaluasi pembelajaran biologi dengan pola lesson studi.

\section{Daftar Pustaka}

Rusman. 2010. Model-Model Pembelajaran: Mengembangkan Profesionalisme Pendidik. Jakarta: Rajawali Pers.

Susilo, H., Chotimah, H., Joharmawan, R., Jumiati, Sari, Y.D., dan Sunarjo. 2010a. Lesson Study Berbasis Sekolah. Malang: Bayumedia Publishing.

Syamsuri, I. \& Ibrohim. 2011. Lesson Study (Studi Pembelajaran). Malang: Penerbit Universitas Negeri Malang 